REGULAR ARTICLE

\title{
EFFECT OF CHICORY LEAF EXTRACT SEED HARDENING CUM FOLIAR SPRAY TO IMPROVE RESULTANT SEED QULAITY IN SESAME (SESAMUM INDICUM L.) CV. TMV3 UNDER RAINFED CONDITION
}

\section{G. SATHIYA NARAYANAN*, B. SUNIL KUMAR, M. PRAKASH, R. ANANDAN}

Department of Genetics and Plant Breeding, Faculty of Agriculture, Annamalai University, Annamalai Nagar 608002, Tamil Nadu, India

\begin{abstract}
An evaluation was carried out to study the effect pre sowing seed treatment and foliar spay with chicory leaf extract on resultant seed quality characters of sesame cv TMV 3. The bulk seeds were graded for uniformity using appropriate round perforated metal sieves of sizes of 5/64" size sieve and were imposed various concentration of chicory leaf extract presowing treatment coupled with foliar spray at different concentration under drought condition. After harvest the resultant seeds were evaluated for its seed qualities. The results revealed that the that the Chicory @ 20 \% Pre sowing seed treatment+Chicory foliar spray @ 30 \% during pod filling stage significantly increased the resultant seed quality characters of the sesame, when compared to other concentration and control.
\end{abstract}

Keywords: Sesame, Chicory leaf extract, Germination, Vigour index

\section{INTRODUCTION}

Oilseeds, the raw material for vegetable oil, occupy a significant place in India's economy. Next to food grains, oilseeds account for 10 per cent of the cultivated area and value of all agricultural produce [1]. Nearly 85 per cent of the oil and fat needs of the country is primarily met by vegetable oils. India is the third largest producer of oilseeds in the world. No other country has its range of perennial and annual oilseeds. Sesame (Sesamum indicum L.) is the third main oilseed crop in India occupying an area of 243.7 lakh hectare with the production of $208.7 \mathrm{l}$ million tonnes and productivity level of $856 \mathrm{~kg} \mathrm{ha}^{-1}$. In Tamilnadu, it is grown in an area of 1.12 lakh hectare with annual production of 0.66 lakh tonnes and has a productivity level of $589 \mathrm{~kg} \mathrm{ha}^{-1}$ [2]. Seed being the basic input in agriculture, production and supply of quality seeds to the farmers will go a long way to achieve the goal of self sufficiency in this oilseed crop. Seed treatment with chemicals are commonly used to ensure uniform stand establishment by improving germination and vigour and protecting against soil borne pathogens and insects [3]. Commonly synthetic fungicides, even though effective, they cause problems of residue retention and nonbiodegradability [4]. Medicinal plants are natures' wonderful gift and used widely in traditional systems like
Ayurveda, Siddha and Unani [5]. Usage of medicinal plants and plant derived compounds in treatment and also in preventing diseases in animals and plants is a common practice [6]. Cichorium intybus, also known by the name chicory (family: Asteraceae) is grown in most of the Asian countries [7]. This plant is highly medicinal and are widely used in traditional as well as modern medicine [8]. Hence the present study, aqueous leaf extract of chicory herbal plant were evaluated for their potency in resultant seed quality parameters in sesame.

\section{MATERIALS AND METHODS}

The present study was carried using genetically pure seeds of sesame (Sesamum indicum L) cv. TMV 3 obtained from the Oilseed Research Station, Thindivanam, Tamilnadu. The experiments were conducted at the Department of Genetics and Plant Breeding, Faculty of Agriculture, Annamalai University, Annamalai Nagar $\left(11^{\circ} 24^{\prime} \mathrm{N}\right.$ latitude and $79^{\circ} 44^{\prime} \mathrm{E}$ longitude with an altitude of $+5.79 \mathrm{mts}$ above mean sea level). The bulk seeds were graded for uniformity using appropriate round perforated metal sieves of sizes of $5 / 64 "$. The chicory herbal leaf extract pre sowing treatment @ 20\% were treated commonly as presowing seed treatment and also used as foliar spray at three concentrations viz., 10.0, 20.0 and $30.0 \%$ to assess the ameliorative effect under rainfed condition.

\footnotetext{
Received 22 March 2018; Accepted 19 April 2018

*Corresponding Author

G. Sathiya Narayanan

Department of Genetics and Plant Breeding, Faculty of Agriculture, Annamalai University, Annamalai Nagar 608002, Tamil Nadu, India

Email: sathiyaa2002@gmail.com

( This article is open access and licensed under the terms of the Creative Commons Attribution License (http://creativecommons.org/licenses/by/4.o/) which permits unrestricted, use, distribution and reproduction in any medium, or format for any purpose, even commercially provided the work is properly cited. Attribution - You must give appropriate credit, provide a link to the license, and indicate if changes were made.
} 


\section{Treatment details}

$\mathrm{T}_{\mathrm{o}}$-Control

$\mathrm{T}_{1}$-Chicory@ 20 \% Pre sowing seed treatment.

$\mathrm{T}_{2}$-Chicory @ $20 \%$ seed hardening treatment+without foliar spray at stress during vegetative stage

$\mathrm{T}_{3}$-Chicory @ $20 \%$ seed hardening treatment+Chicory foliar spray @ 10\% during vegetative stage

$\mathrm{T}_{4}$-Chicory@20\% seed hardening treatment+Chicory foliar spray @ 20\% during vegetative stage

$\mathrm{T}_{5}$-Chicory@20\% seed hardening treatment+Chicory foliar spray @ 30 \% during vegetative stage

$\mathrm{T}_{6}$-Chicory@20\% seed hardening treatment+without foliar spray during flowering stage

$\mathrm{T}_{7}$-Chicory@20\% seed hardening treatment+Chicory foliar spray @ $10 \%$ during flowering stage

T8-Chicory @ $20 \%$ seed hardening treatment+Chicory foliar spray @ $20 \%$ during flowering stage

$\mathrm{T}_{9}$-Chicory@20\% seed hardening treatment+Chicory foliar spray @ 30 \% during flowering stage

$\mathrm{T}_{10}$-Chicory@20\% seed hardening treatment+without foliar spray during pod filling stage

$\mathrm{T}_{11}$-Chicory @ 20 \% seed hardening treatment+Chicory foliar spray @ 10\% during pod filling stage

$\mathrm{T}_{12}$-Chicory @ $20 \%$ seed hardening treatment+Chicory foliar spray @ 20 \% during pod filling stage

$\mathrm{T}_{13}$-Chicory @ $20 \%$ seed hardening treatment+Chicory foliar spray @ 30 \% during pod filling stage

$\mathrm{T}_{14}$-Foliar spray with Brassinolide at all stages of stress+with out foliar spray.

The above treatments were tested for production potential under rainfed condition. The experimental plots were executed with $4 \mathrm{~m} \times 4 \mathrm{~m}$ and the seeds were line sowed and maintained with a spacing of $30 \mathrm{~cm}$ between rows and within a row. The crop was thinned after one week. Normal agronomic package of practices were followed. The experiments were carried out in randomized block design with three replications. From each treatment, 10 plants were selected and the seeds were harvested from the above treatments. The resultant seed characters i.e., germination percentage, shoot length, root length, dry matter production were estimated following the procedure of ISTA, [9], vigour index by Abdul-Baki and Anderson, [10] speed of germination [11], EC [12], catalase activity and peroxidase as per Malik and Singh [13] were recorded. The data were statistically analyzed as per the method of Panse and Sukhatme [14].

\section{RESULTS AND DISCUSSION}

Establishment of a good seedling stand in the field is an important and foremost need for higher crop yield. This depends largely on the field germination and vigour potential of the seeds used for sowing. The results presented in table 1 and 2 revealed that the Chicory @ 20 \% Pre sowing seed treatment+Chicory foliar spray @ 30 \% during pod filling stage improved the resultant seed quality characteristics. In the present study, $\mathrm{T}_{13}$ treatment recoded the higher germination percentage (98\%), lengthier root $(19.9 \mathrm{~cm})$, lengthier shoot $(19.7 \mathrm{~cm})$, higher dry matter production ( $387 \mathrm{mg}$ ) and vigour index (3880), when compared to control and other treatments. The control treatment recorded only lower germination (77 \%), root length $(15.9 \mathrm{~cm})$, shoot length $(12.3 \mathrm{~cm})$, dry matter production $(251 \mathrm{mg}$ ) and vigour index 2171 (table 1). The probable reason may be the presence of tannins and Saponins in the chicory leaf extract, which are the high molecular weight polyphenolic compounds and are efficient antioxidants [15]. This invigourative effect might have rectified the causes of low vigour and improved the seed and seedling characteristics [16]. They are effective free radical scavengers and protect the cell membrane [17]. The above results are in conformity with the previous reports [18-20].

Table 1: Effect of chicory leaf extract seed hardening treatment cum foliar spray on resultant seed quality characters of sesame cv TMV 3

\begin{tabular}{llllll}
\hline Treatments & $\begin{array}{l}\text { Germination } \\
\text { percentage (\%) }\end{array}$ & $\begin{array}{l}\text { Shoot length } \\
\text { (cm) }\end{array}$ & $\begin{array}{l}\text { Root length } \\
\text { (cm) }\end{array}$ & $\begin{array}{l}\text { Dry matter production } \\
\text { (mg. 1o seedlings }\end{array}$ & $\begin{array}{l}\text { Vigour index } \\
\text { (VI) }\end{array}$ \\
\hline $\mathrm{T}_{0}$ & $77(59.02)$ & 12.3 & 15.9 & 251 & $\mathbf{2 1 7 1}$ \\
$\mathrm{T}_{1}$ & $80(60.03)$ & 13.7 & 16.1 & 264 & 2884 \\
$\mathrm{~T}_{2}$ & $80(60.03)$ & 14.2 & 16.1 & 281 & 2424 \\
$\mathrm{~T}_{3}$ & $82(61.36)$ & $15 \cdot 3$ & 16.5 & 297 & 2607 \\
$\mathrm{~T}_{4}$ & $83(64.03)$ & 16.4 & 16.7 & 311 & 2747 \\
$\mathrm{~T}_{5}$ & $85(66.01)$ & 17.6 & 17.0 & 327 & 2941 \\
$\mathrm{~T}_{6}$ & $86(66.14)$ & 17.5 & 17.1 & 320 & 2975 \\
$\mathrm{~T}_{7}$ & $87(67.14)$ & 18.2 & 17.5 & 332 & 3105 \\
$\mathrm{~T}_{8}$ & $88(69.03)$ & 18.1 & 17.7 & 341 & 3150 \\
$\mathrm{~T}_{9}$ & $90(70.62)$ & 18.5 & 18.3 & 344 & 3312 \\
$\mathrm{~T}_{10}$ & $91(72.11)$ & 18.2 & 18.5 & 346 & 3339 \\
$\mathrm{~T}_{11}$ & $92(73.21)$ & 18.6 & 18.7 & 351 & 3431 \\
$\mathrm{~T}_{12}$ & $94(76.12)$ & 19.1 & 19.1 & 358 & 3590 \\
$\mathrm{~T}_{13}$ & $98(87.21)$ & 19.9 & 19.7 & 387 & 3880 \\
$\mathrm{~T}_{14}$ & $94(76.12)$ & 19.4 & 19.3 & 361 & 3637 \\
$\mathrm{MEAN}$ & $87(66.34)$ & 17.1 & 17.6 & 323 & 3088 \\
$\mathrm{CD}(0.05 \%)$ & 3.21 & 1.13 & 0.577 & 21.27 & 48.37 \\
\hline
\end{tabular}

fig. in parenthesis are arcsine transformed value 
Table 2: Effect of chicory leaf extract seed hardening treatment cum foliar spray on resultant seed quality characters of sesame cv TMV 3

\begin{tabular}{lllll}
\hline Treatments & $\begin{array}{l}\text { Speed of } \\
\text { germination }\end{array}$ & $\begin{array}{l}\text { Electrical conductivity (dSm } \\
\text { 1) }\end{array}$ & $\begin{array}{l}\text { Catalase activilty } \\
\text { (Units/g tissue) }\end{array}$ & $\begin{array}{l}\text { Peroxidase activity } \\
\text { (Unit/l) }\end{array}$ \\
\hline $\mathrm{T}_{\mathrm{o}}$ & 7.85 & 0.297 & 2.075 & 2.46 \\
$\mathrm{~T}_{1}$ & 8.11 & 0.291 & 2.232 & 2.65 \\
$\mathrm{~T}_{2}$ & 8.56 & 0.284 & 2.532 & 2.81 \\
$\mathrm{~T}_{3}$ & 9.17 & 0.276 & 2.814 & 2.92 \\
$\mathrm{~T}_{4}$ & 9.62 & 0.267 & 2.978 & 3.06 \\
$\mathrm{~T}_{5}$ & 10.57 & 0.251 & 3.118 & 3.18 \\
$\mathrm{~T}_{6}$ & 10.95 & 0.237 & 3.214 & 3.32 \\
$\mathrm{~T}_{7}$ & 11.24 & 0.211 & 3.324 & 3.46 \\
$\mathrm{~T}_{8}$ & 11.56 & 0.196 & 3.412 & 3.51 \\
$\mathrm{~T}_{9}$ & 12.11 & 0.181 & 3.482 & 3.58 \\
$\mathrm{~T}_{10}$ & 12.84 & 0.164 & 3.507 & 3.73 \\
$\mathrm{~T}_{11}$ & 12.75 & 0.156 & 3.542 & 3.78 \\
$\mathrm{~T}_{12}$ & 13.14 & 0.138 & 3.661 & 3.84 \\
$\mathrm{~T}_{13}$ & 13.99 & 0.124 & 3.999 & 3.87 \\
$\mathrm{~T}_{14}$ & 13.31 & 0.127 & 3.869 & 3.33 \\
$\mathrm{MEAN}$ & 11.05 & 0.213 & 3.176 & 0.25 \\
$\mathrm{CD}(0.05 \%)$ & 0.438 & 0.031 & 0.221 & \\
\hline
\end{tabular}

In the present study, $\mathrm{T}_{13}$ treatment recoded the higher speed of germination (96\%), low EC $\left(0.124 \mathrm{dSm}^{-1}\right)$, higher catalase activity (3.999 unit/g tissue) and higher peroxidase (3.84 Unit/l), when compared to control and other treatments. The control treatment recorded only lowest speed of germination (7.85), high EC $\left(0.297 \mathrm{dSm}^{-1}\right)$, lowest catalase activity (2.075 unit/g tissue) and peroxidase (2.46 Unit/l) (table 2). The probable reason might be the leaf extract of chicory having various phyto chemical components i.e., tannins, saponins, flavonoids, terpenoids, which are non nutritive compounds and play an important role in various functions of growth, thereby improving oxidative process of important macromolecules such as lipids, proteins and nucleic acids [18]. It would have triggered the germination process earlier thereby utilizing the available nutrients. The lowering of electrical conductivity in $\mathrm{T}_{13}$ seeds implies the operation of repair mechanism brought on by chicory leaf extract effect. It is possible that phosphorous along with other minerals and vitamin $\mathrm{C}$ present in chicory leaf extracts would have helped for substitution of scavenging properties to bring down peroxidase changes ultimately maintaining vigour and viability at a higher level [19]. This beneficial effects of chicory leaf extract may be attributed not only to cellular repair but also to the control of free radical reaction. The above results are in conformity with the reports of Vanitha et al. [19] in maize and Vanitha et al. [21] in sunflower, Sathiya Narayanan et al. [20] in sesame. The results revealed that the Chicory @ 20 \% Pre sowing seed treatment+Chicory foliar spray @ 30 \% during pod filling stage significantly increased the resultant seed quality characters of the sesame, when compared to other concentration treatments and control.

\section{ACKNOWLEMENT}

The Authors are very much thankful to UGC, Government of India, New Delhi for the Financial support in the form of major research project

\section{REFERENCES}

1. Acharya SS. Agricultural marketing in India: Some facts and emerging issues. Indian Journal of Agricultural economics. 1998;53:311.
2. Ashraf M, Foolad MR. Pre-sowing seed treatment-A shotgun approach to improve germination, plant growth, and crop yield under saline and non-saline conditions. Advances in Agronomy. 2005;88:223-71.

3. Prakash M, Narayanan GS, Padmavathi S, Kumar BS. Standardization of flyash for seed pelleting in sesame. Agricultural Science Digest. 2015;35:187-90.

4. Kiran B, Raveesha KA. Potential of seeds of Psoralea corylifolia L. for the management of phytopathogenic spp. Archives of Phytopathology and Plant Protection. 2010;43:849-55.

5. Dhiman AK, Kumar A. Ayurvedic drug plants. Daya Books; 2006.

6. Prince L, Prabakaran P. Antifungal activity of medicinal plants against plant pathogenic fungus, Colletotrichum falcatum. Asian Journal of Plant Science and Research. 2011;1:84-7.

7. Bais HP, Ravishankar GA. Cichorium intybus Lcultivation, processing, utility, value addition and biotechnology, with an emphasis on current status and future prospects. Journal of the Science of Food and Agriculture. 2001;81:467-84.

8. Atta AH, Elkoly TA, Mouneir SM, Kamel G, Alwabel NA, Zaher S. Hepatoprotective effect of methanol extracts of Zingiber officinale and Cichorium intybus. Indian Journal of Pharmaceutical Sciences. 2010;72:564.

9. ISTA. 1999. International Rules for Seed Testing. Seed Sci. and Technol., 27:Supplement Rules, 1-84.

10. Abdul-Baki AA, Anderson JD. Vigor determination in soybean seed by multiple criteria 1 . Crop science. 1973;13:630-3.

11. Maguire, I. D, (1962), speed of germination aid in selection and evaluation for seedling emergence and vigour. Crop Sci., 2:176-177

12. Presley, J. T. 1958. Relationship of protoplast permeability of cotton seed viability and predisposition of seedling disease. Pl. Dis. Reptr., 42: 582.

13. Malik, C. P. and Singh, M. B, 91980) Assay of peroxidase. In: Plant Enzymology and Histoenzymology, Kalyani Publishers, New Delhi, p.53.

14. Panse, V. G. and P. V. Sukhatme. 1985. In: Statistical methods for Agricultural workers. ICAR Publication, New Delhi, pp: 327-340. 
15. Rao, A. V. and M. K. Sung. 1995. Saponins as anticarcinogens. J. Nutr. 125: 717-724.

16. Shad, M. A., H. Nawaz, T. Rehman and N. Ikram. 2013. Determination of some biochemicals, phytochemicals and antioxidant properties of different parts of Cichorium intybus L.: A Comparative Study. J. Anim. Plant Sci. 23: 1060-1066.

17. Lobo, V., A. Patil, A. Phatak and N. Chandra. 2010. Free radicals, antioxidants and functional foods Impact. Pharmacogn. Rev. 4: 118-126.

18. Vanitha, C, M. Kathiravan, K. Sujatha and A. Balakrishnan, 2010, Evaluvation of seed quality characteristics in chicory (Cichorium intybus L.), South Indian Hort., 58:163-166.
19. Vanitha C, Ramamoorthy K, Kathiravan M. Influence of herbal seed treatment with chicory (Cichorium intybus L.) and holy basil (Ocimum sanctum) leaf extract on vigour and productivity in maize cv. CO 1 . Research on Crops. 2008;9:116-23.

20. Sathiya Narayanan, G., B. Sunil Kumar, M. Prakash and R. Anandan. 2015. Influence of pre storage herbal seed treatment on storability of sesame cv. TMV 3 . Research Journal of Agricultural Sciences, $6: 53-59$.

21. Vanitha, C. K. Ramamoorthy, M. Kathiravan and K. Sivasubramaniam, 2009. Pre seed storage hydrationdehydration treatment with chicory (Cichorium intybus L.) leaf extract to improve the seed viability during storage in sunflower (Helianthus annuus L) cv Morden. Ad. Plant Sci. 22: 101-104 